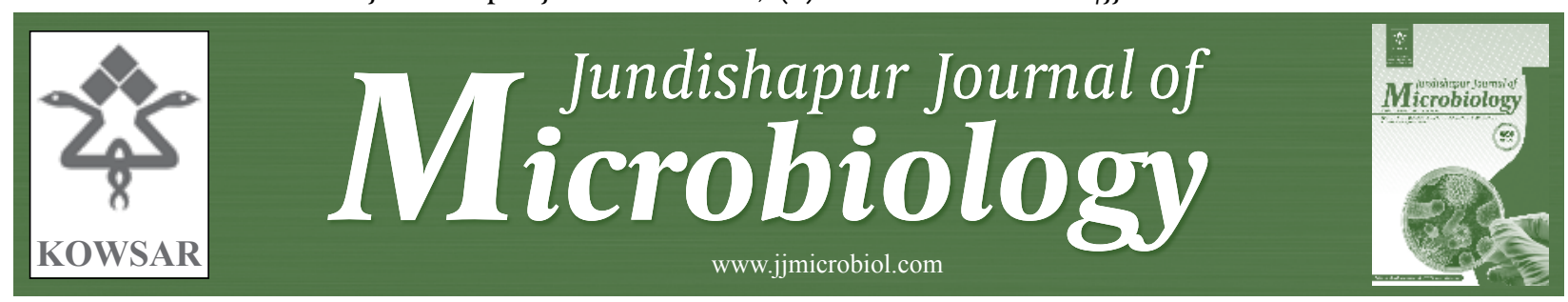

\title{
In Vitro Comparison of the Effects of Garlic Juice and Chlorhexidine Mouthwash on Oral Pathogens
}

\author{
Mansour Amin ${ }^{1^{*}}$, Maryam Kazemi ${ }^{2}$, Neda Rasaie ${ }^{2}$ \\ ${ }^{1}$ Department of Microbiology, school of medicine, Infectious and tropical diseases research center, Ahvaz Jundishapur University of Medical Sciences, \\ Ahvaz, IR Iran \\ ${ }^{2}$ Department of periodontology School of Dentistry, Ahvaz Jundishapur University of Medical Sciences, Ahvaz, IR Iran
}

\begin{tabular}{l}
\hline A R T I C L E I N F O \\
\hline Article type: \\
Original Article \\
\hline Article history: \\
Received: 16 Oct 2011 \\
Revised: 05 Jan 2012 \\
Accepted: 10 Jan 2012 \\
\hline
\end{tabular}

\author{
A B S T R A C T
}

Keywords:

Garlic Juice

Oral Pathogens

Mouthwash

Background: Mouthwash is used to complete the process of mechanical plaque removal. Chlorhexidine is the most common ingredient in mouthwash so we can use it as a gold standard to compare the effects of new products. Garlic is a strong antimicrobial agent and acts as an inhibitor on both Gram-positive and Gram-negative bacteria.

objectives: The present study was conducted to compare the effect that garlic juice and Chlorhexidine mouthwash has on oral pathogens.

Materials and Methods: Fresh garlic bulbs were used to extract the antibacterial juice. The yellow juice was separated from the pulp with Whatman filter paper. After filtration the liquid was freeze dried and stored at $4^{\circ} \mathrm{C}$ until required. The bacteria that were tested were: Streptococcus mutans, S. sanguis, S. salivarius and Lactobacillus casei. After cultivation of the bacteria, the Minimal Inhibitory Concentration (MIC) of the garlic juice and Chlorhexidine were measured using the E-test method, then the Minimal Bactericidal Concentration (MBC) of the Chlorhexidine and garlic juice were measured by tube test.

Results: The lowest MIC of garlic juice was for S. mutans $0.25 \mu \mathrm{g} / \mathrm{mL}$ and the highest was for $L$. casei $2.5 \mu \mathrm{g} / \mathrm{mL}$. The MIC of Chlorhexidine for these two bacteria was $0.62 \mu \mathrm{g} / \mathrm{mL}$ and $5 \mu \mathrm{g} / \mathrm{mL}$ respectively. The MBC of Chlorhexidine and garlic for S. mutans had the lowest concentration compared with the other tested bacteria. The MBC of Chlorhexidine and garlic for S. mutans was $0.35 \mu \mathrm{g} / \mathrm{mL}$ and $0.3 \mu \mathrm{g} / \mathrm{mL}$ respectively. The highest MBC of Chlorhexidine was for S. salivarius $10 \mu \mathrm{g} / \mathrm{mL}$. The MBC of garlic for S. sanguis was similar at $10.4 \mu \mathrm{g} / \mathrm{mL}$.

Conclusions: The efficacy of garlic juice was higher than Chlorhexidine against target bacteria and could be used as an effective mouthwash, but its side effects need to be investigated.

Copyright $\odot 2012$ Kowsar Corp. All rights reserved.

- Implication for health policy/practice/research/medical education:

Garlic is an edible plant that is consumed by humans. Chewing garlic bulbs kills all pathogenic bacteria in the mouth.

- Please cite this paper as:

Amin M, Kazemi M, Rasaie N. In vitro Comparison of the Effects of Garlic Juice and Chlorhexidine Mouthwash on Oral Pathogens. Jundishapur J Microbiol. 2012;5(2):398-400. DOI: 10.5812/jjm.2837

\section{Background}

Chlorhexidine to date has proven to be the most effective anti-plaque agent, and a range of commercial products are available to the public (1). Minor side effects have

* Corresponding author: Mansour Amin, Department of Microbiology, School of Medicine, Infectious and Tropical Diseases Research Center, Ahvaz Jundishapur University of Medical Sciences, Ahvaz, IR Iran. Tel: +989163051096, Fax:+98-6113738204, E-mail: mnsamin@yahoo.com

DOI: $10.5812 / j j m .2837$

Copyright $\odot 2012$ Kowsar Corp. All rights reserved. been reported but these are mainly cosmetic problems. Extrinsic dental staining and taste disturbance are variably the two main side effects of mouth rinse usage, which limit its acceptability to users and the long-term use of this antiseptic in preventive dentistry (2). A large number of bacterial species have become resistant to antibacterial drugs (3-8). This means that there is a need to develoP alternative strategies. Garlic is known to act as an antibiotic, and no resistance to it has been reported (9). Garlic can be administered in the form of capsules 
and powders, as dietary supplements, and thus differs from conventional foods or food ingredients. Louis Pasteur was the first to describe the antibacterial effects of onion and garlic juices. Allium vegetables, particularly garlic (Allium sativum) exhibits a wide range of antibiotic activity against both gram-positive and gram-negative bacteria (10). From the published research articles it is clear that raw garlic juice is effective not only against many common pathogenic bacteria (11) but also against the strains that have become resistant to antibiotics (12) and even the toxic metabolites of some pathogenic bacteria can be inactivated by garlic (13). The common mouthwash Chlorhexidine is a chemical mouthwash and has side effects such as tooth discoloration, changing oral taste and desquamation of oral mucosa.

\section{Objectives}

This study was designed to compare the effects of garlic juice with Chlorhexidine on oral pathogens. The antimicrobial effect of garlic was discovered hundreds of years ago however this is the first time that garlic has been introduced as a mouthwash.

\section{Materials and Methods}

Preparation of the garlic juice: To study the antimicrobial activity of garlic (Allium sativum) in comparison with that of Chlorhexidine (Shahr Daro Company - Iran) against oral bacterial pathogens, 200 gm of fresh garlic was thoroughly washed with tap water and then with sterile distilled water. The juice of the garlic was obtained by crushing the bulbs and filtering with Whatman filter paper number 1. Minimal Inhibitory Concentration (MIC) and Minimal Bactericidal Concentrations (MBC) of garlic juice and Chlorhexidine were determined against target organisms by an E-test and a broth dilution susceptibility test. Determination of MIC was by E-test. Microbial suspensions of freshly grown cultures were prepared in sterile saline. The plates of Mueller Hinton Agar, Hi Media (MHA) were inoculated by dipping a sterile cotton swab into the cell suspension and wiping it across the surface of the agar in three directions. Eight sterile discs (diameter $6 \mathrm{~mm}$ ) were kept on the agar surface in a line. The garlic juice was serially diluted in water and $10 \mu \mathrm{L}$ of each dilution was used separately to inoculate the disc. The plate was incubated for 18 hours at $37^{\circ} \mathrm{C}$. The MIC values were read for the antimicrobial concentrations at the point where dense colonial growth intersected on the disc. The test was performed in quadruplicate for each culture.

Determination of MIC and MBC by broth dilution susceptibility test: In this test the garlic juice was diluted twice in serial tubes and the bacterial suspension was added to the tubes at the same values. The turbidity of the tubes was checked after 24 hours in order to determine the MIC of the juice. The clear tubes were also sub-cultured on agar media (MHA) for determination of their MBC (14). Microorganisms and their maintenance: The target bacteria which were used in this study were
Streptococcus mutans (PTCC1683), S. salivarius (PTCC1448), S. sanguis (PTCC1449), and Lactobacillus casei (PTCC1608), these were obtained from the collection center of fungi and bacteria, Tehran, Iran. All bacteria were stored in trypticase soy broth containing $25 \%$ (v/v) glycerol (Merck) and refreshed on MHA media before use.

\section{Results}

The results of this study showed that the growth of all tested microorganisms was stopped by the garlic juice; it also had bactericidal effects on all the target bacteria. The lowest level of MIC for garlic juice was for Streptococcus mutans, which was $0.25 \mu \mathrm{g} / \mathrm{mL}$ and the highest was for Lactobacillus casei $2.5 \mu \mathrm{g} / \mathrm{mL}$. The MIC of Chlorhexidine for these two bacteria was 0.62 and $5 \mu \mathrm{g} / \mathrm{mL}$ respectively (Table 1). The MBC of Chlorhexidine and garlic for S. mutans had the lowest concentration than that of the other tested bacteria. The MBC of Chlorhexidine and garlic for S. mutans was 0.35 and 0.3 $\mu \mathrm{g} / \mathrm{mL}$ respectively. The highest $\mathrm{MBC}$ of Chlorhexidine was for S. salivarius, $(10 \mu \mathrm{g} / \mathrm{mL})$ while the MBC of garlic for S. sanguis was almost the same, $10.4 \mu \mathrm{g} / \mathrm{mL}$ (Table 2).

Table 1. MIC of Chlorhexidine and Garlic Juice against Oral Pathogenic Bacteria by E-Test

\begin{tabular}{lll}
\hline & $\begin{array}{l}\text { Chlorhexidine } \\
\mathbf{M I C}^{\mathbf{a}}, \mu \mathbf{g} / \mathbf{m L}\end{array}$ & $\begin{array}{l}\text { Garlic Juice } \\
\mathbf{M I C}^{\mathbf{a}}, \mu \mathbf{g} / \mathbf{m L}\end{array}$ \\
\hline Lactobacillus casei & 5 & 2.5 \\
Streptococcus mutans & 0.62 & 0.25 \\
Streptococcus sanguis & 2.5 & 0.4 \\
Streptococcus salivarius & 0.35 & 0.3 \\
\hline
\end{tabular}

${ }^{a}$ Abbreviations: MIC, Minimal inhibitory concentration

Table 2. MBC of Chlorhexidine and Garlic Juice Oral Pathogen Bacteria by Tube Dilution Method

\begin{tabular}{lll}
\hline Target Bacteria & $\begin{array}{l}\text { Chlorhexidine } \\
\mathbf{M B C}^{\mathbf{a}}, \mu \mathbf{g} / \mathbf{m L}\end{array}$ & $\begin{array}{l}\text { Garlic Juice } \\
\mathbf{M B C}^{\mathbf{a}}, \mu \mathbf{g} / \mathbf{m L}\end{array}$ \\
\hline Lactobacillus casei & 7.8 & 15 \\
Streptococcus mutans & 1.9 & 1.5 \\
Streptococcus sanguis & 1.9 & 10.4 \\
Streptococcus salivarius & 10 & 10 \\
\hline
\end{tabular}

${ }^{a}$ Abbreviations: MBC, Minimal Bactevieidal concentration

\section{Discussion}

Today the most commonly used chemical substance for oral plaque control is Chlorhexidine mouthwash. Unfortunately Chlorhexidine has side effects such as tooth discoloration, oral mucosal exfoliation, etc. So many investigators have researched herbal extracts to prevent plaque accumulation on teeth and use them as alternatives instead of chemical substances $(2,15)$. Garlic is a member of the Allium family and many members of this genus have medicinal application as anti-microbial, anti-infective and anti-fungal agents. Today we know the role of this family in the prevention and treatment of many diseases (16). 
Regarding a study at Hawassa University, garlic was found to have antimicrobial effects on Staphylococcus aureus (17), Belgunith et al. showed that garlic extract prevented the growth of Salmonella in vitro. Salmonella is a significant pathogen in food poisoning (18). According to the results obtained in this study all of the tested bacteria were sensitive to garlic juice but $\mathrm{S}$. mutans was more sensitive than the others. The results of MBC of garlic also confirmed the cidal effect of the juice of this plant. Amin et al. investigated in vitro antimicrobial and antifungal effects of garlic and onion extracts on 23 species of fungi and bacteria. The results showed that the antimicrobial effect of garlic was greater than that of the onion extract (19).

With regard to the results of this present study, garlic juice was more effective against oral pathogens when compared with Chlorhexidine mouthwash and can be recommended as a new type of mouthwash. However its side effects must first be investigated and more studies need to be conducted concerning the pathogenic effects of garlic juice on epithelium and other cells.

\section{Acknowledgments}

None declared.

\section{Financial Disclosure}

All authors declare that they have no conflict of interest.

\section{Funding/Support}

This study is financially has supported by research affairs, Ahvaz Jundishapur University of Medical sciences.

\section{References}

1. Jenkins S, Addy M, Newcombe R. Comparison of two commercially available chlorhexidine mouthrinses: II. Effects on plaque reformation, gingivitis, and tooth staining. Clin Prev Dent. 1989;11 (6):12-6.
2. mathur S, mathur T, shrivastava R, khatri R. Chlorhexidine:The gold standard in chemical plaque control. Natl J Physiol Pharm Pharmacol. 2011;1(2):45-50.

3. Chadwick D, Goode J. Antibiotic resistance: origins, evolution, selection, and spread. Wiley; 1997.

4. Cohen ML. Epidemiology of drug resistance: implications for a post-antimicrobial era. Science. 1992;257 (5073):1050-5.

5. Cole AM, Hong T, Boo LM, Nguyen T, Zhao C, Bristol G, et al. Retrocyclin: a primate peptide that protects cells from infection by T-and M-tropic strains of HIV-1. Proc Nat Acad Sci. 2002;99 (4):1813.

6. Kiessling CR, Cutting JH, Loftis M, Kiessling WM, Datta AR, Sofos JN. Antimicrobial Resistance of Food-Related Salmonella Isolates, 1999-2000. J Food Protect. 2002;65(4):603-8.

7. Teuber M. Spread of antibiotic resistance with food-borne pathogens. Cell Mol Life Sci. 1999;56 (9):755-63.

8. Walsh C. Molecular mechanisms that confer antibacterial drug resistance. Nature. 2000;406 (6797):775-81.

9. El Astal Z. The inhibitory action of aqueous garlic extract on the growth of certain pathogenic bacteria. Eur Food Res Technol. 2004;218 (5):460-4.

10. Whitemore B, Naidu A. Thiosulfinates. Natural Food Antimicrobial Systems, CRC Press, Boca Raton, Florida, USA. 2000:265-380.

11. Kumar A, Sharma VD. Inhibitory effect of garlic (Allium sativum Linn. ) on enterotoxigenic Escherichia coli. Indian J Med Res. 1982;76 Suppl:66-70.

12. Jezowa L, Rafinski T, Wrocinski T. Investigations on the antibiotic activity of Allium sativum L. Herba Pol.1966;12:3-13.

13. Dewit J, Notermans S, Gorin N, Kampelmacher E. Effect of garlic oil or onion oil on toxin production by Clostridium botulinum [food poisoning bacteria] in meat slurry.J Food Prot (USA). 1979.

14. Levison ME. Pharmacodynamics of antimicrobial drugs. Infect Dis Clin North Am. 2004;18(3):451-65, vii.

15. Barkvoll P, Rolla G, Svendsen K. Interaction between chlorhexidine digluconate and sodium lauryl sulfate in vivo. J Clin Periodontol.1989;16 (9):593-5.

16. Cowan MM. Plant products as antimicrobial agents. Clinical Microbiol Rev. 1999;12 (4):564.

17. Deresse D. Antibacterial Effect of Garlic (Allium sativum) on Staphylococcu aureus: An in vitro Study. Asian J Med Sci. 2010;2 (2):62-5.

18. Belguith H, Kthiri F, Chati A, Sofah AA, Hamida JB, Ladoulsi A. Inhibitory effect of aqueous garlic extract (Allium sativum) on some isolated Salmonella serovars. African J Microbiol Res. 2010;4 (5):328-38.

19. Amin M, Kapadnis BP. Heat stable antimicrobial activity of Allium ascalonicum against bacteria and fungi. Indian J ExP Biol. 2005;43 (8):751-4. 